\title{
The Contribution of a State-Owned Enterprise to Regional, Industrial and Agricultural Production in Turkey: An Example of Ülfet Stock Company of Food and Soap Industry
}

Asst.Prof.Dr. Ahmet Oğuz

\author{
Karabuk University, Faculty of Economics and Administrative Sciences \\ Department of Economics, Karabuk/Turkey \\ ahmetoguz@karabuk.edu.tr
}

Research Asst. Ali Rauf Karataş

Karabuk University, Faculty of Economics and Administrative Sciences

Department of Economics, Karabuk/Turkey

aliraufkaratas@karabuk.edu.tr

Research Asst. Tuğçe Olcay

Karabuk University, Faculty of Economics and Administrative Sciences

Department of Economics, Karabuk/Turkey

tugceolcay@karabuk.edu.tr

\section{Assoc.Prof.Dr. Mustafa Günay}

Karabuk University, Faculty of Engineering, Department of Mechanical Engineering, Karabuk/Turkey

Doi:10.5901/mjss.2014.v5n13p294 mgunay@karabuk.edu.tr

\begin{abstract}
In the mixed economy which private and public enterprises are active in economic life, have their primary goal which is to maximize social prosperity. Public enterprises in Turkey were used to function as a means of economic improvement in parallel with the role of government in the 20th century. Public enterprises out of the aimed social prosperity, they have certain political aims of accomplishing resource allocation, fair income distribution and sustainable growth. These lead to some problems of public enterprises which have strengthened the privatization arguments especially through the end of 20th century. The aim of this study has to investigated (stay away from the controversial issue of privatization and the focus on) the activities of a public enterprise and its contribution to local and national economy. So we will focus on Ülfet Stock Company of Food and Soap Industry which was established in Gaziantep, in 1955 to produce olive oil, soap and glycerin and privatized in 2001. The establishing a public enterprise in this region has to increases a culture of industrialization and regional, agricultural production as well as added value. The result of this study has significant implications for public enterprise. Local governments and policy makers in their search of strategies for improving the roles of public and private enterprises in economy.
\end{abstract}

Keywords: State-Owned Enterprise, Economic Development, Privatization, Food and Soap Industry, Turkey

\section{Introduction}

Since the existence of the government, it has been seen that the government has interfered directly or indirectly in the economy. The interference of the government to the economy might be not only rule maker but also ragulatory (Atasoy, 1993: 11). The historical origins of the governement entrepreneurship in Turkey date back to the Ottoman Empire. However, it was late 1920s that The Republic of Turkey decided to use the governement entrepreneurship as a means of economical development and growth. Until 1920s, the government enterprises which were founded and run in Ottoman days intended to bring the public services to the public with more independent institutions in parallel with the other economies of the world. On the other hand, the fact that the government used the commercial and industrial enterprises which government established as a means of economic development started during the World War II and just after the World War II (Aysan, 1973: 106). It could be shown among the main reasons of this period that the extraordinary conditions which the war revealed were effective and the changes happened in favour of J.M. Keynes based government 
interference in the economy paradigm after the great depression (Pınar, 2010: 6).

In the first years of the Republic which is the beginning of a new period, Izmir Economy Congress became decisive in shaping the economic structure of Turkey. The government was expected to take a regulatory and supportive task on the activities of the private enterprises in the congress held in 17th February-4th March 1923. However, in the incoming years the government started to take the responsibility of economic activities indirectly because of the results caused by the great great depression and the internal dynamics of the government itself (Akkoyunlu, 2011: 54.). As a result of this, "protectionism and statism" which were the features of 1930-1939 period in the economy of Turkey appeared. Nevertheless, it could be said that those were the years when The Rebuplic of Turkey began its industrialization (Boratav, 2012: 59). Even though Turkey did not crusade actively in the World War II between the years 1940-1950, its economy was managed through" the conditions of the war". The period after 1960 was the beginning of a new period for building the economy policy and making economic decisions. From this date on, Turkey started a planned progress and an economic development which was inward-looking and foreign-dependent (Buluş, 2009: 88). With the legal regulations made in this period when the mixed economy policies continued, a general arrangement which was related to the status, organizations, managements and supervisions of the government business enterprises was made. Also, the useful regulations which were made to provide the necessary loans for the investments of the government business enterprises increased the number of the government business enterprises established rapidly in Turkey (Dirican, 1997: 53). Until 1980s, the influence of the government business enterprises increased as a means of employment, added-value and fixed capital investments in Turkey's economy (Tansel, 2003: 9). After 1980, with the acceleration of the liberalization flow, the influence of the government business enterprises on the economy decreased relatively and the privatization activities accelerated.

One of the important government business enterprises which was established after 1960 the planned period was Ülfet Food and Soap Incorporated Company. Although the company was founded according to the Turkis Commercial Law rules in 1952, it was able to start its activities in 1964. The government business enterprise which was founded in Nizip, Gaziantep, would have big effects that could change the economic, social and demographic environment of the region ( The Republic Archive of the Pime Ministry, The State Auditing Board of the Prime Ministry, Ülfet Food and Soap Industry Incorporated Company 1964-1965, 1965-1966 and 1966-1967 Reports).

\section{The Definition of the Government Business Enterprises}

There is no widely accepted definition for the government business enterprises. The most important reason of this is the diversity of the views among the international institutions which work on the government business enterprises. For example, while the English use the term "nationalized industry" mostly, the French use the term "the government enterprises" (Aysan and Özmen, 1981: 3). The government business enterprises could be defined widely as " the institutions which has a legal entity, an industrial and commercial qualification, and whose capital belongs entirely or mostly* to the government" (Dirican, 1997: 13).

\section{The Historical Development of the Government Business Enterprises in Turkey}

In paralel with increasing of the economic functions of the government in the 20th century, the government business enterprises were the resources of the development of economic policies. Especially in the developing countries, it became a flexible means of economic development strategies. It is possible to say that the appearance and development of the government business enterprises in Turkey have became within the frame of the development strategies applied since 1923. The origin of the government business enterprises dates back to the Ottoman period and it was in the Republic period that the government business enterprises became the means of development (Kök, 1995: 63).

The first period which lasted from 1923 about to 1930 carries the traces of Izmir Economic Congress (17 February4 March) when İstanbul was being occupied and before the Republic was declared (Kazgan, 2006: 55). The most significant aim determined in this congress was the necessity of industrialism of Turkey as soon as possible no matter it takes (Ünal, 2000: 10). Although the opportunities were provided for the national private enterprises in this direction, the private enterprise was deprive of the dynamics which would instigate the economy in this period (Kök, 1995: 64). In this congress, it was foreseen that the development would occur as a means of the private sector ,and before the decisions made in this congress were put into practice completely, the economies of Turkey and the world faced with the 1929 
great depression. Just after this crisis in parallel with the condition of the world, Turkey started to found the government enterprises regularly like many other countries of the world. But these enterprises were thought temporarily and aimed at improving and supporting the economy until the private enterprises recovered and strengthened. After the I. Five-Year Development Plan was put into practice in 1933, the number of the government enterprises continued to rise. Even if the liberal flow was seen in the economy of Turkey after 1950, the increase in the number of the government business enterprises continued. The main reason of this was that the private sector couldn't afford to establish some facilities (Ünal, 2000: 11). 1960s were the years when the "social state" or "welfare state" concepts were applied in practice in every area ( Sezen, 1999: 174). After 1960, the planned period began in Turkey. From this date on, the development plans were prepared as five-year periods and they were put into practice. When looked at the content of the development plans, 1980 could be named as the breakage year. Because Turkey stopped the strategy of the import substitution industrialization in this period and instead turned to the external oriented industrialization strategy. Also the significant arrangements were made in the free market rules to command the economy. As a natural result of these policy proposals, the operations of the privatization of the government business enterprises accelerated (Ünal, 2000: 13). Similarly in the 20th century, the privatization process of the big government business enterprises and infrastructures has been continuing.

\section{The Activities of Ülfet Food and Soap Industry Incorporated Company}

\subsection{The Establishment of the Company}

Ülfet Food and Soap Industry Inc. Was established according to the rules of Turkish Commercial Law in order to produce olive oil, soap and glycerin. The center of the company is in Nizip. The duration of the company is 90 years. With the effect of the law number 23 on 20 July 1960, it was subject to the supervision of the State Auditing Board. As a result of this, the company was inspected between the years 1964-1980 by the State Auditing Board and the data obtained from these inspections were presented in reports (Başbakanlık Cumhuriyet Arşivi, Başbakanlık Yüksek Denetleme Kurulu, Ülfet Gıda ve Sabun Sanayii Anonim Şirketi 1964-1965, 1965-1966, 1966-1967 Yılları Raporu). The company capital which was 2 million Liras in its first establishment was raisen to 6 million in 1962, 8.3 million in 1963 and 35 million in 1964. The aim of the company in brief according to the master agreement is to produce oil for cooking and soap, and fruit and vegetables juice, canned goods, soap and glycerin, and to evaluate the wastes of them and to set up a box and package plant ( The Republic Archive of the Prime Ministry, The State Auditing Board of the Prime Ministry, Ülfet Food and Soap Industry Inc. Company The Periodic Report of 1.7.1968-30.6.1969 ).

\subsection{The Activities of the Business}

\subsubsection{The Production Activities and The Quantity of Sales}

The production amount of Ülfet Food and Soap Industry Inc. Company, which virtually produces olive oil and soap and also evaluates the side products and manufactures them, between the years 1964-1967 comparatively with the work programmes is below

Table-1: The Production Amount of the Company Between the Years 1964-1967

\begin{tabular}{|l|c|c|c|c|c|c|}
\hline \multirow{2}{*}{ Name of Product } & \multicolumn{2}{|c|}{$1964-1965$} & \multicolumn{2}{c|}{$1965-1966$} & \multicolumn{2}{c|}{$1966-1967$} \\
\cline { 2 - 7 } & Planned (Ton) & Ex-post (Ton) & $\begin{array}{c}\text { Planned } \\
\text { (Ton) }\end{array}$ & $\begin{array}{c}\text { Ex-post } \\
\text { (Ton) }\end{array}$ & $\begin{array}{c}\text { Planned } \\
\text { (Ton) }\end{array}$ & $\begin{array}{c}\text { Ex-post } \\
\text { (Ton) }\end{array}$ \\
\hline Black olives in brine & 250 & 80 & 100 & 24 & 100 & 8 \\
\hline Green olives in brine & 50 & 9 & - & - & - & - \\
\hline Natural olive oil & 1140 & 281 & 575 & 164 & 1380 & 938 \\
\hline Refined olive oil & 850 & 907 & 2000 & 1566 & 1376 & 2354 \\
\hline Packaged olive oil & - & 463 & 680 & 1445 & 1060 & 337 \\
\hline Packaged refined cottonseed oil & - & 199 & 451 & 468 & 1857 & 417 \\
\hline Pomace 1 oil & 640 & 429 & 560 & 307 & 380 & 392 \\
\hline White soap & 4500 & 3459 & 3800 & 3006 & 330 & 3807 \\
\hline
\end{tabular}

\footnotetext{
${ }^{1}$ Pomace olive oil in terms of the wealth lost after tightening smoking, used as fertilizer or animal feed meal. www.tdk.gov.tr
} 


\begin{tabular}{|l|c|c|c|c|c|c|}
\hline Green soap & 500 & 193 & 400 & 242 & 400 & 266 \\
\hline Second type of Green soap & - & 67 & 300 & 342 & 300 & 213 \\
\hline Presses soap & 150 & 15 & - & - & - & 37 \\
\hline Soap powder & 150 & 45 & 120 & 53 & 50 & 54 \\
\hline Detergent & - & - & - & 37 & 450 & 85 \\
\hline Glycerin & 145 & 135 & 180 & 88 & 100 & 110 \\
\hline Grape honey & 100 & 20 & - & - & - & - \\
\hline
\end{tabular}

Source: The Republic Archive of the Prime Ministry, The State Auditing Board of the Prime Ministry, Ülfet Food and Soap Industry Inc. Company Report of the Years 1964-1965, 1965-1966 and 1966-1967.

In this term except for a few products, the company was not be able to reach the amount which it had aimed in the work programme. When looked at the total value, the relative success of the company stood out. In the period of 1964-1965, the company planned 8475 tons of production in all of the products and managed 6302 tons of production at the end of the period. In other words,in this period it could manufacture $\% 74$ of the production which it had targeted. In the period of 1965-1966, 9166 tons of production was determined in the work programmes ,and at the end of the period 7742 tons of production happened and \%85 of targeted production was reached in this period. In the period of 1966-1967, 7783 tons of production were planned and 9018 tons of production happened, and the amount of the production happened more than targeted production. Consequently, even though the company couldn't reach its targets on the production based in this three-year period, as of total production amounts it provided consistent results.

The production amounts of Ülfet Food and Soap Industry Inc. Company between the years 1972-1980 are below:

Table-2: The Production Amounts of the Company Between the Years 1972-1980

\begin{tabular}{|c|c|c|c|c|c|c|c|c|c|c|}
\hline \multirow[b]{2}{*}{ Name of Product } & \multicolumn{2}{|c|}{1972} & \multicolumn{2}{|c|}{1974} & \multicolumn{2}{|c|}{1976} & \multicolumn{2}{|r|}{1978} & \multicolumn{2}{|r|}{1980} \\
\hline & $\begin{array}{c}\text { Amount } \\
\text { (Ton) }\end{array}$ & \begin{tabular}{|c|} 
Ex-post \\
Rate (Ton)
\end{tabular} & $\begin{array}{c}\text { Amount } \\
\text { (Ton) }\end{array}$ & $\begin{array}{c}\text { Ex-post Rate } \\
\text { (Ton) }\end{array}$ & $\begin{array}{l}\text { Amount } \\
\text { (Ton) }\end{array}$ & $\begin{array}{c}\text { Ex-post Rate } \\
\text { (Ton) }\end{array}$ & $\begin{array}{c}\text { Amount } \\
\text { (Ton) }\end{array}$ & $\begin{array}{c}\text { Ex-post Rate } \\
\text { (Ton) }\end{array}$ & $\begin{array}{c}\text { Amount } \\
\text { (Ton) }\end{array}$ & $\begin{array}{c}\text { Ex-post Rate } \\
\text { (Ton) }\end{array}$ \\
\hline Black olives in brine & 240 & 80,4 & 185 & 78,4 & 151,5 & 75,7 & 167,7 & 64,5 & 82,9 & 37,7 \\
\hline Natural olive oil & 600 & 106,3 & 278 & 18,5 & 665 & 66,5 & 141,8 & 14,1 & 198,6 & 26,5 \\
\hline Pomace oil & 460 & 87,3 & 911.2 & 91,1 & 790 & 98,7 & 465,1 & 42,2 & 150 & 22,4 \\
\hline Wood briquettes & 2.500 & 108,6 & 1.510 & 60,4 & 1.192 & 39,7 & 1.571 & 104,7 & 1.256 & 31,4 \\
\hline Refined olive oil & 3.440 & 55,7 & 1.065 & 71,2 & 1.716 & 62,1 & 2.569 & 51,2 & 850,1 & 34,7 \\
\hline Refined cottonseed oil & 1.940 & 11,1 & 122,9 & 68,2 & 256,7 & 23,1 & 99,5 & 43,7 & 72 & 37,8 \\
\hline Refined sunflower oil & 1.170 & 81,2 & 77,8 & 55,8 & 444,1 & 32,5 & 4.492 & 54,1 & 925 & 52,5 \\
\hline Chandeliers olive oil & 550 & 77,9 & 29,8 & 16,5 & 196,9 & 60,3 & - & - & - & - \\
\hline Various kinds of soap & 4.130 & 80 & 4.020 & 88,7 & 5.720 & 96,2 & 4.601 & 61,0 & 2.032 & 38,3 \\
\hline Detergent & 170 & 79 & 37 & 21,7 & 128,5 & 85,6 & 71,7 & 71,7 & 191,7 & 127,8 \\
\hline Glycerin & 120 & 31,3 & 37,6 & 31,3 & 58,5 & 59,6 & 28,8 & 24,0 & 24,3 & 40,5 \\
\hline Flour & & & 6.055 & 50,4 & 3.326 & 35,7 & 6.566 & 70,5 & 4.971 & 62,1 \\
\hline
\end{tabular}

Source: The Republic Archive of the Prime Ministry, The State Auditing Board of the Prime Ministry, Ülfet Food and Soap Industry Inc. Company Report of the Years 1972, 1974, 1976, 1980.

The Mediterranian Area is an intensive olive cultivation region. Ülfet Food and Soap Industry Inc. Company was founded in order to evaluate the product of olive trees which is available in the regions of South and South-East of the country. In the period of the years 1972-1980, the production of the company was under the capacity mostly. The main reasons of this were the increase in the raw materials, inadequateness of the business capital and especially that the market department couldn't operate in desired activities.

In addition to the production results of the company, the quantity of the sales should be one of the important indicators. In the first three-year period of the company (1964-1967), the production sales increased \%150 in the threeyear term. This shows a fast development in the activities of the company. Also in this period, soap and olive oil were the significant parts of the sales of the company. The company lost money only in 1964 in this period but it made a profit in the following two years. In the following years, the company was consistent in the quantity of the sales, its style and method (The Republic Archive of the Prime Ministry, The State Auditing Board of the Prime Ministry, Ülfet Food and Soap Industry Inc. Company the Report of the Years 1964-1965, 1965-1966 and 1966-1967, 1970, 1972, 1974, 1976, 1978, 1979, 1980). 


\subsubsection{The Employment Opportunities}

The company has employed staff as the officers, contracted personel and workers. The numbers of the staff who the company employed are in the table by years:

Table-3: The Company's Personnel Status

\begin{tabular}{|l|c|c|c|c|c|}
\hline \multicolumn{1}{|c|}{ Years } & Board of Directors & Auditors & Number of officers & Number of worker & Total Number of Employees \\
\hline 1964-1965 Period & 4 & 2 & 39 & 295 & 340 \\
\hline 1965-1966 Period & 5 & 2 & 34 & 278 & 319 \\
\hline 1966-1967 Period & 5 & 2 & 42 & 348 & 397 \\
\hline 1967-1968 Period & - & 2 & 28 & 288 & 318 \\
\hline $1968-1969$ Period & - & 3 & 26 & 277 & 306 \\
\hline $1969-1970$ Period & - & - & 25 & 355 & 380 \\
\hline $1970-1971$ Period & - & - & 34 & 355 & 389 \\
\hline 1972 & - & - & 40 & 528 & 569 \\
\hline 1973 & - & - & 46 & 423 & 470 \\
\hline 1974 & - & - & 48 & 449 & 498 \\
\hline 1975 & - & - & 64 & 537 & 601 \\
\hline 1976 & - & - & 65 & 500 & 565 \\
\hline 1977 & - & - & 61 & 371 & 434 \\
\hline 1978 & - & - & 59 & 401 & 460 \\
\hline 1979 & - & - & 72 & 396 & 468 \\
\hline 1980 & - & - & 62 & 355 & 417 \\
\hline
\end{tabular}

Source: The Republic Archive of the Prime Ministry, The State Auditing Board of the Prime Ministry, Ülfet Food and Soap Industry Inc. Company the Report of the Years 1964-1965, 1965-1966 and 1966-1967, 1970, 1972, 1974, 1976, 1978, 1979, 1980.

The number of the staff who the company employed was consistent in the parallel with the production activities of the company. It is seen that there is a continuous increase in the average income of the officers and workers. The total number of the staff who the company employed has a significant importance when looked at the demographic structure of the period and the working population of Nizip. For instance, the popularion of Nizip between the years 1960-1980 was 55.000 in average. In this period when the women employment was very low, the importance of the employment numbers of the company could be seen better when looked at the men population in the active population.

\section{Conclusion}

Even though the interference of the government to the economy sometimes increases and sometimes decreases dependently, it has always appeared. The government business enterprises has been among the interference methods of the government to the economy. In the applications of nationalization and forming of the government business enterprise system, the ideology and political structure, the practical solution seeking for the economic problems, the historical reasons and the stabilization and the economic development patterns were determiners. In the first years of the Republic which was the beginning of a new period, the war conditions were determinative not only in the political and social structure of the country but also in the economic structure of the country like in the whole world. The big destruction which the war created ruined the budgets and the economies of the countries, and stopped the development thrusts of the countries. As the results of all of these, the countries felt obliged themselves to interfere in the economy.

Turkey couldn't stay out of these developments which started at the beginning of the 20th century and caused the expansion of the government sector. In this period, the most intensive interference of the country to the economy was running a business directly and the number of the government business enterprises increased rapidly in the economy of Turkey. Although not only the political authorities who adopted the "nationalism" principle but also the parties who had a liberal view took part in the management of the country until 1980s, the government business enterprises kept their importance and intensity. However, Turkey got influenced by the liberalism which dominated the world after 1980 and the important steps were taken with the decisions which were made on 24 January 1980 to enter the free market economy. In the results of these steps, the function of the government on the economy was decreased and the privatization activities accelerated. 
In the periods when the establishments of the government business enterprises, Ülfet Food and Soap Industry Inc. Company took its part in the government business enterprises. This government business enterprise which was established in the South-East Anatolian region which could be said as the homeland of the olive tree carried out its production activities and targets in accordance with the advantages of the geography where it was founded. The most intensive production area of the company was olive oil and soap. When it is thought that the South-East Anatolian region where the company was founded is the first region in producing olives in Turkey, it could be said that the government business enterprise brought an industry culture in the region. One of the other important results of specialising of the region in the agricultural production is the deduction effect on the interregional disequilibrium. For example, there was relatively a development difference between the East and the West of the country in favour of the West from the first years of the Republic. The activities of the company encouraged the private sector and provided a supplementary function for the private sector.

Ülfet Food and Soap Industry Inc. Company was privatized in 2001. We could reach the detailed data of the years 1964-1980 about its activities due to the reports of the State Auditing Board. The olive cultivation has an important place in the agriculture in Turkey. It is seen that the olive oil industry in Turkey has improved since 1950. The contributions of Ülfet which was the second biggest food and industry complex when founded couldn't be ignored in this development.

\section{References}

Altınok, T. (1982). Kamu İktisadi Teşekküleri Sorunları ve Çözüm Yolları (Problems and Solutions of State-Owned Enterprıses). Ankara: Başbakanlık Basımevi

Atasoy, V. (1993). Türkiye'de Kamu Iktisadi Teşebbüsleri Özelleştirme Sorunu (Problem of Privatization of Public Enterprises in Turkey), Ankara

Aysan, Mustafa A. (1973). Türkiye'de Devlet İşletmeciliği (State Management in Turkey), İstanbul: Yalkın Ofset Matbaası

Aysan, M. ve Özmen, S. (1981). KiT Türkiye'de ve Dünyada Kamu İktisadi Teşebbüsleri (SOE State Owned Enterprises in Turkey and in the World), İstanbul: Kardeşler

Boratav, K. (2012). Türkiye İktisat Tarihi 1908-2009 (Economic History of Turkey 1908-2009), İstanbul: IMGE

Başbakanlık Cumhuriyet Arşivi, Başbakanlık Yüksek Denetleme Kurulu, Ülfet Gıda ve Sabun Sanayii Anonim Şirketi 1964-1965, 19651966, 1966-1967 Yılları Raporu (The Republic Archive of the Pime Ministry, The State Auditing Board of the Prime Ministry, Ülfet Food and Soap Industry Incorporated Company 1964-1965, 1965-1966 and 1966-1967 Reports), Ankara

Başbakanlık Cumhuriyet Arşivi, Başbakanlık Yüksek Denetleme Kurulu, Ülfet Gıda ve Sabun Sanayii Anonim Şirketi 1.7.1968- 30.6.1969 Dönemi Raporu (The Republic Archive of the Prime Ministry, The State Auditing Board of the Prime Ministry, Ülfet Food and Soap Industry Inc. Company The Periodic Report of 1.7.1968-30.6.1969), Ankara

Başbakanlık Cumhuriyet Arşivi, Başbakanlık Yüksek Denetleme Kurulu, Ülfet Gıda ve Sabun Sanayii Anonim Şirketi 1970 Yılı Raporu (The Republic Archive of the Prime Ministry, The State Auditing Board of the Prime Ministry, Ülfet Food and Soap Industry Inc. Company Report of the Year 1970), Ankara

Başbakanlık Cumhuriyet Arşivi, Başbakanlık Yüksek Denetleme Kurulu, Ülfet Gıda ve Sabun Sanayii Anonim Şirketi 1972 Yllı Raporu (The Republic Archive of the Prime Ministry, The State Auditing Board of the Prime Ministry, Ülfet Food and Soap Industry Inc. Company Report of the Year 1972), Ankara

Başbakanlık Cumhuriyet Arşivi, Başbakanlık Yüksek Denetleme Kurulu, Ülfet Gıda ve Sabun Sanayii Anonim Şirketi 1974 Yılı Raporu (The Republic Archive of the Prime Ministry, The State Auditing Board of the Prime Ministry, Ülfet Food and Soap Industry Inc. Company Report of the Year 1974), Ankara

Başbakanlık Cumhuriyet Arşivi, Başbakanlık Yüksek Denetleme Kurulu, Ülfet Gıda ve Sabun Sanayii Anonim Şirketi 1976 Yılı Raporu (The Republic Archive of the Prime Ministry, The State Auditing Board of the Prime Ministry, Ülfet Food and Soap Industry Inc. Company Report of the Year 1976), Ankara

Başbakanlık Cumhuriyet Arşivi, Başbakanlık Yüksek Denetleme Kurulu, Ülfet Gıda ve Sabun Sanayii Anonim Şirketi 1978 Yılı Raporu (The Republic Archive of the Prime Ministry, The State Auditing Board of the Prime Ministry, Ülfet Food and Soap Industry Inc. Company Report of the Year 1978), Ankara

Başbakanlık Cumhuriyet Arşivi, Başbakanlık Yüksek Denetleme Kurulu, Ülfet Gıda ve Sabun Sanayii Anonim Şirketi 1979 Yılı Raporu (The Republic Archive of the Prime Ministry, The State Auditing Board of the Prime Ministry, Ülfet Food and Soap Industry Inc. Company Report of the Year 1979), Ankara

Başbakanlık Cumhuriyet Arşivi, Başbakanlık Yüksek Denetleme Kurulu, Ülfet Gıda ve Sabun Sanayii Anonim Şirketi 1980 Yılı Raporu (The Republic Archive of the Prime Ministry, The State Auditing Board of the Prime Ministry, Ülfet Food and Soap Industry Inc. Company Report of the Year 1980), Ankara

Buluş, A. (2009). Türk İktisat Politikalarının Tarihi Temelleri(Turkish Historical Foundations of Economic Policy), Konya: Tablet Kitapevi

Dirican, A. (1997). Türkiye'de Kamu İktisadi Teşebbüslerinin Özelleştirimesi Politikaları ve Sonuçları(Privatization of Public Enterprises in Turkey Policies and Results), Çanakkale.

Feyzioğlu Akkoyunlu, P. (2011), Kamu İktisadi Teşebbüsleri ve Özelleştirme(Public Enterprises and Privatization), İstanbul: Beta.

Kazgan, G. (2006). Tanzimat'tan 21. Yüzyıla Türkiye Ekonomisi (Reform in the 21st Century Economy of Turkey), İstanbul: İstanbul Bilgi Üniversitesi Yayınları. 
Kök, R. (1995). Ekonomi- Politik Popülizm Özelleştirme ve Kitler (Political Economy of Populism and Mass Customization), İstanbul: Dergah Yayınları.

Pınar, A. (2010), Maliye Politikası Teori ve Uygulama (Fiscal Policy in Theory and Practice), Ankara.

Sezen, S. (1999), Devletçilikten Özelleştirmeye Türkiye'de Planlama (Planning from statism to Privatization in Turkey), Ankara.

Ünal, Firdevs F. (2000), Özelleştirmenin Kamu İktisadi Teşebbüslerinde Verimlilik Üzerine Etkisi -Türkiye Şeker Sektörü Uygulaması (Impact of Privatization on Productivity in Public Economic Enterprises-Turkey Sugar Sector App.), Ankara.

Tansel, A. (2003), Kit'ler ve Özelleştirme: İddialar ve Gerçekler (Soe and Customization: Claims and Facts), Ankara: Türk-Iş Araştırma Merkezi. 